NOTE

\title{
A decrease in fledging body mass in common guillemot Uria aalge chicks in the Baltic Sea
}

\author{
Henrik Österblom ${ }^{1, *}$, Anders Bignert ${ }^{2}$, Thord Fransson $^{3}$, Olof Olsson ${ }^{4}$ \\ ${ }^{1}$ Department of Vertebrate Zoology, ${ }^{2}$ Contaminant Research Group, and ${ }^{3}$ Bird Ringing Centre, Swedish Museum of Natural History, \\ PO Box 50007, 10405 Stockholm, Sweden \\ ${ }^{4}$ Formas, PO Box 1206, 11182 Stockholm, Sweden
}

\begin{abstract}
Chick fledging body mass of the common guillemots Uria aalge breeding at Stora Karlsö in the Baltic Sea between 1989 and 2000 were studied in order to reveal any effects of an increased abundance of their main prey species, sprat Sprattus sprattus. Chick fledging body mass has decreased during the study period, and so has the condition of sprat. The deteriorated condition of the prey is most probably responsible for the observed decreased fledging body mass in guillemot chicks. This study shows that the condition of fish preyed upon by seabirds, in addition to availability, may be an important factor when studying seabird-fish interactions. It is clearly indicated that changes in the sprat population, as a consequence of changes in the Baltic Sea, have affected common guillemot fledging body mass.
\end{abstract}

KEY WORDS: Common guillemot · Uria aalge · Fledging body mass $\cdot$ Sprat $\cdot$ Baltic Sea

Resale or republication not permitted without written consent of the publisher

Large-scale oceanographic changes with consequences for marine birds have been observed in many places, for example in the North Sea (Aebischer et al. 1990), off the coast of California (Ainley et al. 1995, 1996, Veit et al. 1996), off the coast of British Columbia (Bertram et al. 2001) and in the Gulf of Alaska (Piatt \& Anderson 1996, Anderson \& Piatt 1999).

Cairns (1987) predicted that breeding parameters for seabirds, such as chick growth, are sensitive to low food availability; however, when seabirds are able to switch to alternative prey, availability of preferred prey could vary considerably before changes in chick growth occur. Chick growth and/or fledging body mass have been shown to correlate with availability of preferred food for several seabird species (rhinocerous auklet Cerorhinca monocerata: Bertram \& Kaiser 1993; Atlantic puffin Fratercula arctica: Barrett et al. 1987,

*E-mail: henrik.osterblom@nrm.se
Anker-Nilssen \& Øyan 1995; king penguin Aptenodytes patagonicus: Olsson 1997; common tern Sterna hirundo: Greenstreet et al. 1999). Feeding rates and chick growth for common guillemot chicks were unaffected despite large fluctuations in availability of preferred prey at colonies where alternative prey was available. This was because the parents compensated for a low abundance of prey by spending more time foraging and less time resting at the breeding site and/or by taking alternative prey (Burger \& Piatt 1990, Zador \& Piatt 1999). The common guillemot is thus relatively insensitive to changes in available prey when alternative prey sources are available.

However, in the Shetland Islands where common guillemots depend on 1 type of food, chicks of a given age were heavier in a year when food was more abundant and feeding rates were higher (Uttley et al. 1994). This suggests that food availability in the poor year was below the threshold value for normal chick growth and that the adults were not able to compensate for the low food availability by increasing foraging activities.

Common guillemots in the Baltic Sea feed their chicks almost exclusively with sprat (Hedgren 1976). The stock of sprat in the Baltic Sea in 1998 was roughly twice that of 1975 (Anonymous 2000a). The most dramatic changes in sprat spawning biomass occurred during the nineties, when it increased more than 4 -fold between 1989 and 1997, from 362000 to $1485000 \mathrm{t}$ (Anonymous 2000a). The spawning biomass in 2000 was estimated to be $868000 \mathrm{t}$ (Anonymous 2000a).

The increase in abundance of sprat has been suggested to be mainly a result of low mortality due to reduced predation pressure from cod Gadus morhua, as this species has decreased dramatically since the late 1980s (Kaljuste 1999, Anonymous 2000a,b, Hjerne 2000). The dominating fish in the Baltic Sea system has hence changed from cod to clupeids (sprat 
and herring Clupea harengus), which therefore has implications for the entire ecosystem. Sprat is of increasing commercial importance in the Baltic Sea and catches increased more than 5-fold in the 1990s (Anonymous 2000a). The condition of sprat is related to abundance of zooplankton, which in turn is affected by hydrological processes in the Baltic Sea, e.g. salinity (Raid \& Lankov 1995, Flinkman et al. 1998, Vourinen et al. 1998, Kaljuste 1999). The surface salinity in the central Baltic Sea has decreased between 1980 and 1998 (J. Rohde pers. comm.). In this paper, we investigate the fledging body mass of common guillemot chicks leaving the colony at Stora Karlsö in 1989, and between 1991 and 2000, in order to determine whether the change in prey density has affected chick fledging body mass.

Methods. Ringing and weighing of common guillemot chicks on Stora Karlsö $\left(57^{\circ} 17^{\prime} \mathrm{N}, 1^{\circ} 58^{\prime} \mathrm{E}\right)$ were performed during the last week of June or the 1st week of July in all years. Ringing was performed in the same part of the colony every year during the peak of the fledging period. Chicks were caught on their way from the nest site to the sea. The number of chicks ringed and weighed varied between years (range 208 to 790 , except for 1 yr when only 46 chicks were ringed and weighed due to less ringing activity). Hedgren (1979) found that mean fledging body mass of chicks fledging at Stora Karlsö decreased by an average of $2.6 \mathrm{~g} \mathrm{~d}^{-1}$ after the median fledging date. Thus, chicks fledging early or in the peak of the fledging season weighed more than those fledging later. To decrease the effects of a lower mean fledging body mass due to this seasonal variation, chicks weighed after 4 th July were excluded from the sample. We thus conclude that all chicks included in the analysis were weighed at or near median fledging date (Hedgren 1979).

Hedgren (1979) found that pre-breeding climatic condition for adults (February to May) affected the timing of breeding (i.e. warm spring = early breeding). Multiple regression analyses were used to investigate the relationships between fledging body mass of common guillemot chicks and mean deviation from longterm average air temperature in February to May and also in June. All temperatures were measured at Visby airport (the nearest weather station) and provided by the Swedish Meteorological and Hydrological Institute. Long-term average air temperatures were determined from 1961 to 1990. Body mass measurements were adjusted by means of ANCOVA, and log-linear simple regression analyses were used to estimate the temporal trend of body mass.

All information on sprat spawning biomass and condition (mean body mass at different ages) is according to official ICES statistics and relates to studies of sprat made in the fall of every year, i.e. after the common guillemot breeding season.

Results and discussion. Results showed a negative correlation between fledging body mass and deviation from long-term average air temperature of June $(\mathrm{p}<$ 0.006 ) but no correlation ( $p>0.05$ ) for mean deviation from long-term average air temperature of February to May. Analyses also demonstrated that: (1) unadjusted body mass over time decreased significantly $(p<0.019)$ by $0.81 \% \mathrm{yr}^{-1}$; (2) body mass for each year adjusted for deviation from long-term average air temperature of June, decreased $(\mathrm{p}<0.006)$ by $0.62 \% \mathrm{yr}^{-1}$ (Fig. 1); and (3) to see whether leverage effect of the low average body mass of 1999 had a decisive influence on the

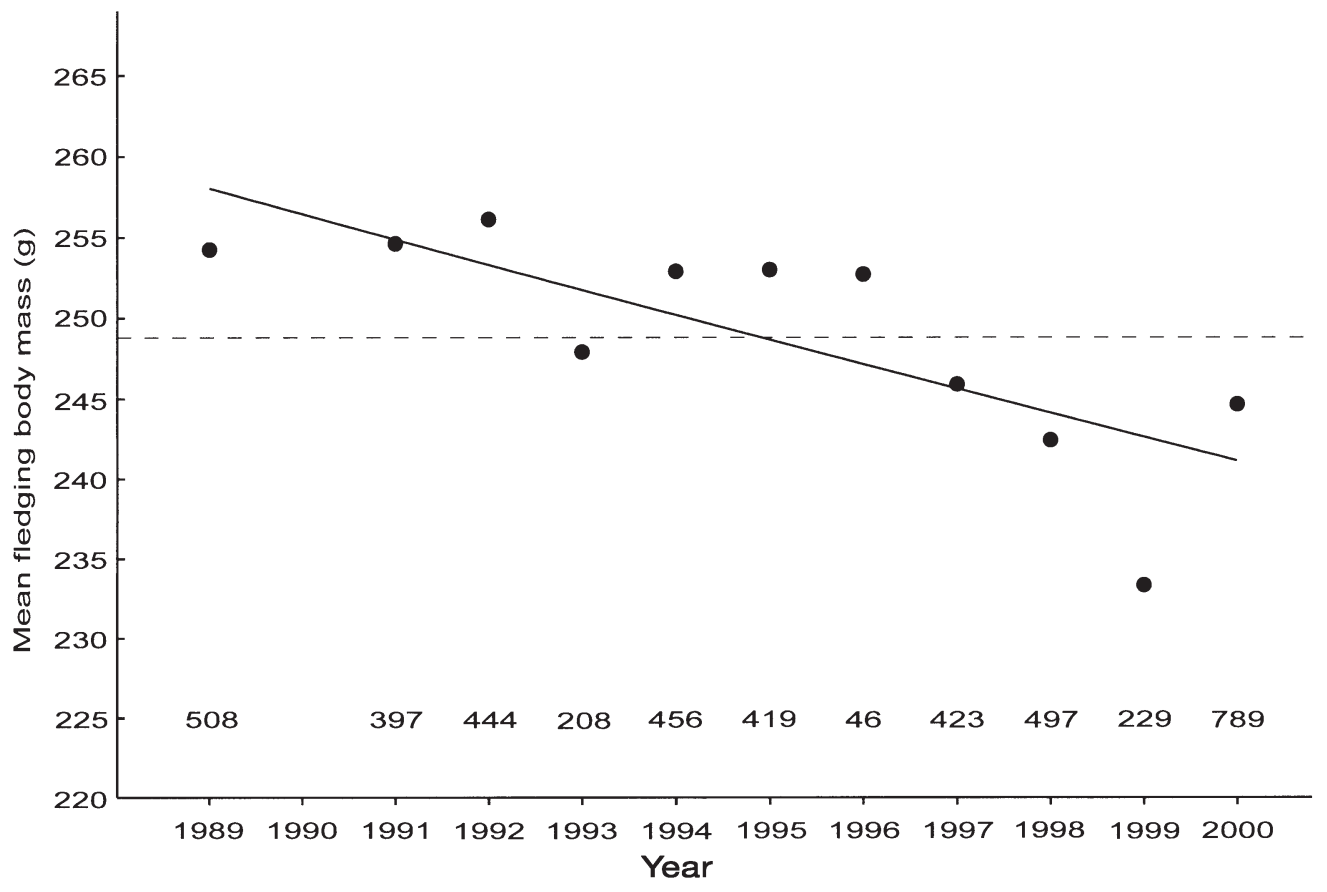

Fig. 1. Common guillemot chick fledging body mass adjusted for deviation from longterm average air temperature of June. Sample sizes are indicated in the figure 
Fig. 2. The condition (mean weight at age) for sprat in the Baltic Sea, age classes 2

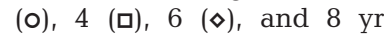
and older $(\bullet)$. All data from Anonymous (2000a)

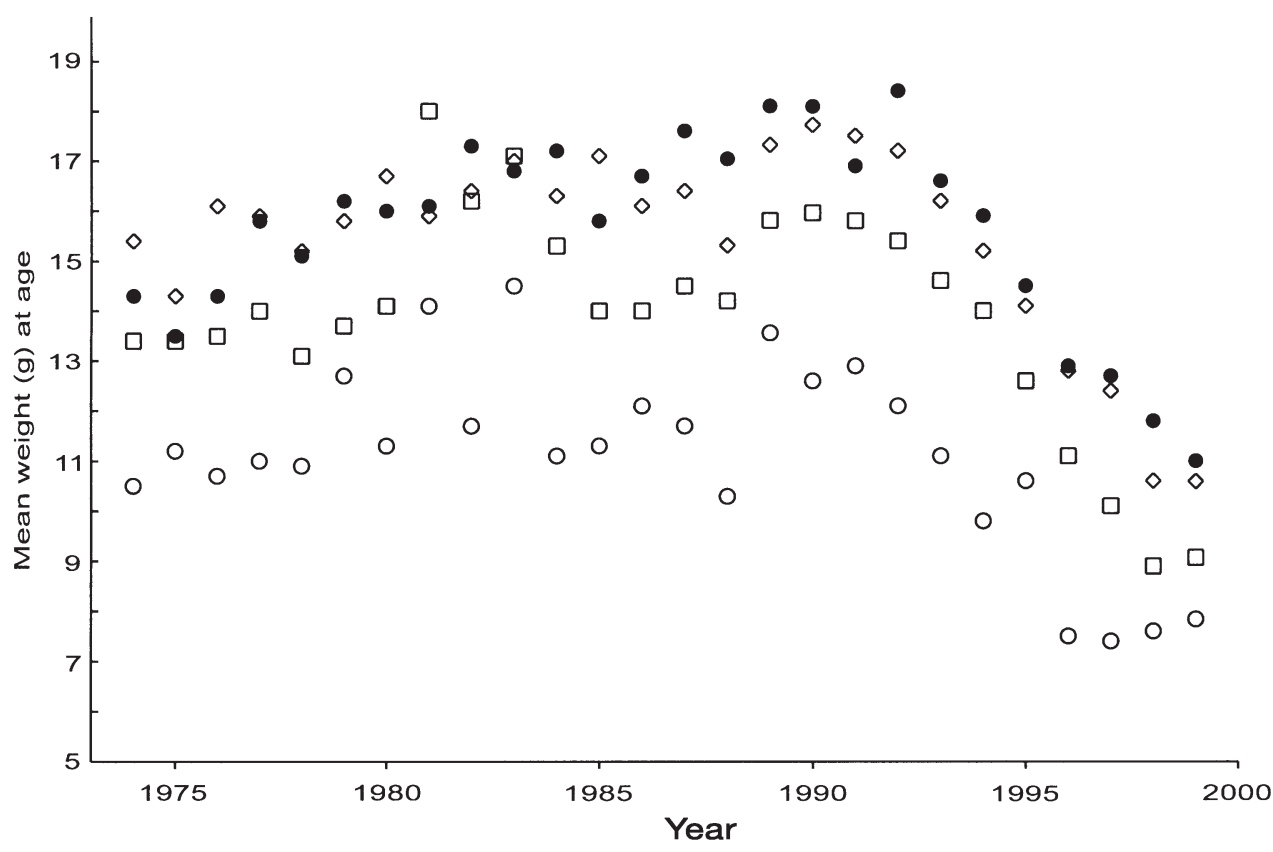

analysis, we did the same regression analysis as in point 2 but without including the 1999 data in the analysis, this also resulted in a significant decrease $(\mathrm{p}<$ 0.008 ) of $0.44 \% \mathrm{yr}^{-1}$. We conclude that there is a significant decrease over time of about $0.5 \% \mathrm{yr}^{-1}$. This corresponds to a decrease of mean fledgling body mass of about $15 \mathrm{~g}$, (6\%) since the beginning of the $1990 \mathrm{~s}$. The average fledging body mass in the beginning of this study (early 90s) was similar to average fledging body mass found during the 1970 s (i.e. 253.7 g, Hedgren 1979) indicating that the decrease in fledging body mass started recently.

Common guillemots spend relatively little time together at the breeding site when food is scarce and relatively more time when food is abundant (Burger \& Piatt 1990, Monaghan et al. 1994, Uttley et al. 1994, Zador \& Piatt 1999). Breeding pairs of common guillemots at Stora Karlsö spent a lot of time together at the breeding ledge in 1998 (pers. obs), suggesting that they were not under food stress, but had a large amount of time available for additional foraging. In addition, durations of feeding trips in 1998 were short, indicating that food was easily accessible (pers. obs.). However, this study suggests that in recent years, the chicks have received less energy from the food. Digestive constraints and net energy gained from the ingested food could explain why the chicks are not fed more when the parents are not foraging at a maximum rate and food is easily accessible. Digestive constraints experienced by the chick may determine the amount of food delivered by the parent. Atlantic puffins respond to the nutritional state of their chicks (Harris 1983, Johnsen et al. 1994, Wernham \& Bryant 1998) but it is unknown whether guillemots respond in a similar way. Physical satiation appeared to limit food intake more efficiently than any other stimuli for steller sea lions Eumetopias jubatus (Rosen \& Trites 2000).

The marine fish community structure in the Gulf of Alaska ecosystem has undergone large changes as a consequence of a shift in ocean climate (Anderson \& Piatt 1999). Steller sea lions in this area have switched from high-energy prey (herring) to low-energy prey (pollock Theragra chalcogramma), which has negatively affected the sea lion population (Rosen \& Trites 2000). Captured sea lions fed exclusively with pollock were unable to maintain their weight as a result of the low energy gained and the cost of digestion. It was calculated that they needed to consume 35 to $80 \%$ more pollock than herring in order to maintain a comparable net energy intake (Rosen \& Trites 2000). This has been referred to as the junk-food hypothesis. Common guillemots in the Gulf of Alaska have also switched prey type, coupled with population declines (Piatt \& Anderson 1996). Common guillemots are specialised in feeding on readily digestible, energy dense food and have a relatively fast and inefficient digestion (Hilton et al. 2000a,b). Common guillemots fed with lowenergy pout Trisopterus esmarki were unable to maintain body mass (Hilton et al. 2000a).

The condition (measured as body mass at a given age) of sprat in the Baltic Sea was relatively stable between 1974 and 1989 when the population was correspondingly stable (spawning biomass). However, the population increased dramatically in the 1990s and the condition of different age classes of sprat decreased by an average of $40 \%$ (Fig. 2). Changes in growth for 
herring and sprat in the Baltic Sea show similar trends although the deteriorated condition of herring was evident earlier (Kaljuste 1999, Anonymous 2000a). Changes in herring condition has been attributed to a decline in biomass of preferred zooplankton (Flinkman et al. 1998). The 2 species feed, in part, on the same species of zooplankton (Rudstam et al. 1992, Arrhenius 1996, Raid \& Lankov 1995). Energy density in fish is determined mainly by the fat content (Hilton et al. 1998, 2000b). The fat content of herring in the Baltic Proper has decreased dramatically since the late 1970s until today ( $\AA$ djers et al. 2000). It is possible that the fat content and hence energy density of sprat has decreased as well.

During the last half of the 1990s, mean weight at age for all age classes of sprat in the Baltic Sea was below the average weight of sprat taken by guillemots in 1975, which was 13.3 g. (Hedgren 1976; Fig. 2). Energy density has been shown to increase with size for sprat (Arrhenius 1998, Hilton et al. 1998); hence, during recent years, guillemots at Stora Karlsö were forced to prey on smaller sprat containing a lower energy density. The change in fledging body mass, which coincides with the deteriorated condition of sprat, clearly suggests a decrease in the daily calorific intake and net energy gained by the chick. The calculated daily calorific intake for common guillemot chicks at Stora Karlsö in 1975 was 368 kJ (Harris \& Wanless 1985). The present daily calorific intake for common guillemot chicks in the Baltic Sea is not known.

This study clearly indicates that changes in the Baltic Sea zooplankton and fish fauna have affected common guillemot fledging body mass in this area.

Acknowledgements. We would like to thank G. Hoas, B. Lilja and all volunteers working with the ringing of chicks at Stora Karlsö. We would also like to thank A. Bruzelius for assistance in handling data. We are grateful to 4 anonymous referees for valuable comments on the manuscript. This study was in part financed by the Swedish World Wildlife Fund, WWF. Logistical support was provided by Karlsö Jagt och Djuskyddsförening.

\section{LITERATURE CITED}

Ådjers K, Sandström O, Bignert A (2000) Fisk och fiskefisketrycket för hårt (Fishery in trouble with English summary). In: Tidlund A, Brenner U (eds) Östersjö '99 Årsrapport från miljöövervakningen $\mathrm{i}$ egentliga Östersjön (Swedish Marine Monitoring in the Baltic Proper). Stockholm Marine Research Center, p 35-36

Aebischer NJ, Coulson JC, Colebrook JM (1990) Parallel long-term trends across four marine trophic levels and weather. Nature 347:753-755

Ainley DG, Sydeman WJ, Norton J (1995) Upper trophic level predators indicate interannual negative and positive anomalies in the California food web. Mar Ecol Prog Ser 118: 69-79
Ainley DG, Spear LB, Allen SG (1996) Variation in the diet of cassin's auklet reveals spatial, seasonal, and decadal occurrence patterns of euphausiids off California, USA. Mar Ecol Prog Ser 137:1-10

Anderson PJ, Piatt JF (1999) Community reorganization in the Gulf of Alaska following ocean climate regime shift. Mar Ecol Prog Ser 189:117-123

Anker-Nilssen T, Øyan HS (1995) Hekkebiologiske langtidsstudier av lunder på Røst (English summary). NINA. Fagrapport 015

Anonymous (2000a) Report of the Working Group on Baltic Fisheries Assessment. ICES CM 2000/ACFM:14. Part 2

Anonymous (2000b) Report of the Working Group on Ecosystem Effects of fishing activities. ICES CM 2000/ACME: 02, p 19-24

Arrhenius F (1996) Diet composition and food selectivity of 0-group herring (Clupea harengus L.) and sprat (Sprattus sprattus (L.)) in the northern Baltic Sea. ICES J Mar Sci 53: 701-712

Arrhenius F (1998) Food intake and seasonal changes in energy content of young Baltic Sea sprat (Sprattus sprattus L.). ICES J Mar Sci 55:319-324

Barrett RT, Anker-Nilssen T, Rikardsen F, Røv N, Vader W (1987) The food, growth and fledging success of Norwegian puffin chicks Fratercula arctica in 1980-1983. Ornis Scand 18:73-83

Bertram DF, Kaiser GW (1993) rhinoceros auklet (Cerorhinca monocerata) Nestling diet may gauge Pacific sand lance (Ammodytes hexapterus) recruitment. Can J Fish Aquat Sci 50:1908-1914

Bertram DF, Mackas DL, McKinnell SM (2001) The seasonal cycle revisited: interannual variation and ecosystem consequences. Prog Oceanogr 49:283-307

Burger AE, Piatt JF (1990) Flexible time budgets in breeding common murres: buffers against variable prey abundance. Stud Avian Biol 14:71-83

Cairns DK (1987) Seabirds as indicators of marine food supplies. Biol Oceanogr 5:261-271

Flinkman J, Aro E, Vuorinen I, Viitasalo M (1998) Changes in northern Baltic zooplankton and herring nutrition from 1980s to 1990s: top-down and bottom-up processes at work. Mar Ecol Prog Ser 165:127-136

Greenstreet SPR, Becker PH, Barrett RT, Fossum P, Leopold MF (1999) Consumption of pre-recruit fish by seabirds and the possible use of this as an indicator of fish stock recruitment. In: Furness RW, Tasker ML (eds) Diets of seabirds and consequences of changes in food supply. ICES cooperative research report, No. 232, p 6-17

Harris MP (1983) Parent-young communication in the puffin Fratercula arctica. Ibis 125:109-114

Harris MP, Wanless S (1985) Fish fed to young guillemots Uria aalge, and used in display on the Isle of May, Scotland. J Zool Lond 207:441-458

Hedgren S (1976) Om sillgrisslans Uria aalge föda på Stora Karlsö. (On the food of the guillemot Uria aalge at the island of Stora Karlsö, the Baltic Sea). Var Fagelvarld 35: $287-290$

Hedgren S (1979) Seasonal variation in fledging weight of guillemots Uria aalge. Ibis 121:357-361

Hilton GM, Houston DC, Furness RW (1998) Which component of diet quality affect retention time of digesta in seabirds? Funct Ecol 12:929-939

Hilton GM, Furness RW, Houston DC (2000a) A comparative study of digestion in North Atlantic seabird. J Avian Biol 31:36-46

Hilton GM, Furness RW, Houston DC (2000b) The effects of 
diet switching and mixing on digestion in seabirds. Funct Ecol 14:145-154

Hjerne O (2000) Fish and fisheries management in an ecological context, with emphasis to the Baltic Sea. Licentiate Thesis, Stockholm University

Johnsen I, Erikstad KE, Saether B-E (1994) Regulation of parental investment in a long-lived seabird, the puffin Fratercula arctica: an experiment. Oikos 71:273-278

Kaljuste O (1999) Change in the growth and stock structure of Baltic sprat (Sprattus sprattus) in the Gulf of Finland in 1986-97. Proc Est Acad Sci Biol Ecol 48:296-309

Monaghan P, Walton P, Wanless S, Uttley JD, Burns MD (1994) Effects of prey abundance on the foraging behaviour, diving efficiency and time allocation of breeding guillemots Uria aalge. Ibis 136:214-222

Olsson O (1997) Effects of food availability on fledging condition and post-fledging survival in king penguins. Polar Biol 18:161-165

Piatt JF, Anderson P (1996) Response of common murre to the Exxon Valdez Oil Spill and Long-Term Changes in the Gulf of Alaska Marine Ecosystem. In: Rice SD, Spies RB, Wolfe DA, Wright BA (eds) Exxon Valdez oil spill symposium proceedings. American Fisheries Society Symposium, Bethesda, MD 18:720-737

Raid T, Lankov A (1995) Recent changes in the growth and

Editorial responsibility: Otto Kinne (Editor),

Oldendorf/Luhe, Germany feeding of Baltic herring and sprat in the northeastern Baltic Sea. Proc Est Acad Sci Ecol 5:38-55

Rosen DAS, Trites AW (2000) Pollock and the decline of steller sea lions: testing the junk-food hypothesis. Can J Zool 78: $1243-1250$

Rudstam LG, Hansson S, Johanson S, Larsson U (1992) Dynamics of planktivory in a coastal area of the northern Baltic Sea. Mar Ecol Prog Ser 80:159-173

Uttley JD, Walton P, Monaghan P, Austin G (1994) The effects of food abundance on breeding performance and adult time budgets of guillemots Uria aalge. Ibis 136: 205-213

Veit RR, Pyle P, McGowan JA (1996) Ocean warming and long-term change in pelagic bird abundance within the California current system. Mar Ecol Prog Ser 139:11-18

Vuorinen I, Hänninen J, Viitasalo M, Helminen U, Kuosa H (1998) Proportion of copepod biomass declines with decreasing salinity in the Baltic Sea. ICES J Mar Sci 55: $767-774$

Wernham CV, Bryant DM (1998) An experimental study of reduced parental effort and future reproductive success in the puffin, Fratercula arctica. J Anim Ecol 67:25-40

Zador SG, Piatt JF (1999) Time-budgets of common murres at a declining and increasing colony in Alaska. Condor 101: $149-152$

Submitted: June 12, 2001; Accepted: September 30, 2001

Proofs received from author(s): November 26, 2001 